\title{
SELECTED ASPECTS OF MEASURING PERFORMANCE OF SMART CITIES IN SPATIAL MANAGEMENT
}

\author{
Slawomira Hajduk \\ Faculty of Management, Bialystok University of Technology, \\ Oj. Tarasiuka 2 Str., 16-001 Biatystok, Poland \\ E-mail: s.hajduk@pb.edu.pl
}

\begin{abstract}
This paper explains the meaning of the term smart in the context of city management through an approach based on relevant scientific literature review as well as official documents of international institutions. It also identifies key elements characterizing a smart city. Furthermore, the study shows how to measure and compare urban smartness for instance using ISO 37120 Standard. The test procedure used taxonomic methods such as Hellwig's synthetic indicator. The main goal of the research is to analyze and evaluate of the smartness cities in Poland. The result of the study is the author's ranking of Polish cities in view of their level of smartness. The most smartness cities proved Polish metropolises (Wrocław, Katowice, Poznań, Kraków), tourist cities (Sopot, Łeba, Jastarnia, Władysławowo), suburban cities (Podkowa Leśna, Zielonka, Pruszcz Gdański) and post-mining cities (Chorzów, Gliwice, Siemianowice Śląskie).
\end{abstract}

Keywords: smart cities in Poland, ISO 37120, urban development, spatial management, taxonomic methods, Hellwig's synthetic indicator.

JEL Classification: O18; O31.

\section{Introduction}

In the last three decades, the concept of smart city has become more and more popular in scientific literature and international policies in particular urban spatial management (European Union 2014). Cities play a huge role in social and economic aspects worldwide and have a major impact on the natural environment. Whereas only 10 percent of the world's population lived in cities in 1900, urbanization is a defining phenomenon of the $21^{\text {st }}$ century. Currently cities produce greater than 75 percent of global GDP. The world's urban population will double from 2010 (2.6 billion) to 2050 (5.2 billion) (Lierow 2014; United Nation 2015). The importance of urban area as a global occurrence is confirmed by the diffusion of megacities of more than 20 million people in Asia, Latin America and Africa.

The need for globally comparable data and knowledge on cities has never been greater. The ISO 37120:2014: Sustainable Development of Communities - Indicators for City Services and Quality of Life is the first standard of the International Organization for Standardization concerned with city metrics. It defines and establishes methodologies to be used with a set of indicators which steer and measure the performance of city services and quality of life. ISO 37120:2014 can be applied to any city, municipality or local government, irrespective of size and location.
This study aims to analyze and evaluate the smartness of cities in Poland. The research included 304 cities of Poland. The main result is the author's ranking of Polish cities in view of their level of smartness. The author used statistical data from the Local Data Bank of the Central Statistical Office and reports prepared by the Institute of Geography and Spatial Organization of the Polish Academy of Sciences, the International Organization for Standardization and the European Union. The test procedure covered the taxonomic methods such as Hellwig's synthetic indicator.

\section{Background literature}

Smart cities are areas of high concentrations of learning and innovation. In such territories creativity, innovation and entrepreneurship, connected with digital infrastructure, aspire to stimulate economic growth, sustainable development and a better quality of life for citizens (Schaffers et al. 2011; Shapiro 2006). The smart city has a variety of definitions and interpretations (Chourabi et al. 2012; Hernández-Muňoz et al. 2011; Ricciardi, Za 2014). The concept of smart city is an attempt to answer problems such as urbanization, aging of social infrastructure, congestion, reduction of $\mathrm{CO}_{2}$ emissions (Richter et al. 2015; Cocchia 2014; Paskaleva 2009). The smart city is concerned primarily with the integration of Information \& Communica-

(C) 2016 The Authors. Published by VGTU Press. This is an open-access article distributed under the terms of the Creative Commons Attribution License (CC-BY 4.0), which permits unrestricted use, distribution, and reproduction in any medium, provided the original author and source are credited. 
tion Technologies with processed performed in the city (those concerning urban infrastructures, including: energy, water, buildings, transportation, communications, administrative services) with the aim to obtain optimal efficiency of these processes (Dameri, Cocchia 2013; Papa et al. 2013). This integration results from strategy, planning, and programs developed by ICT companies for municipal authorities, e.g. Toshiba, Ericsson, Cisco, IBM, Siemens, Apple.

The term "smart city" was first used in the 1990s (Tranos, Gertner 2012; Bakici et al. 2013; Sainz Pena 2011). At that time, the meaning focused on new information technologies with regard to modern infrastructures within cities. Smart city refers to the interception of data through the use of sensors, meters and appliances and the integration of that data in a computing platform that allows the communication of such information to various city services allowing them to make better operational decisions (Allwinkle, Cruickshank 2011; Dameri 2013; Tachizawa et al. 2015). Some years later, scientific institutes and public agencies started crit- icizing the idea of smart cities as being too technically oriented and claimed that smart city should emphasize the role of human capital. A few years ago researchers started to show the social aspects within the context of a smart city. Within that concept particularly interesting is the inclusion of the quality of life of the citizens of that city (Shapiro 2006; Batagan 2011). Other interpretations suggest that smart implies intelligent, because that smartness is realized only when an intelligent system adapts itself to the users' needs (Leydesdorff, Deakin 2011; Lombardi 2011). In literature it is acknowledged that there is a lack of a consensus on how to classify smart cities. The line between smart cities and similar concepts such as creative and intelligent cities is vague. Thus, there exists a need for a clear definition of the determinants of a smart city which is consensually accepted. Table 1 outlines some of the different definitions and meanings of the concept of a smart city in the chronological order. It also explains that ICT in cities should be used in every subsystem to improve quality of life of citizens.

Table 1. Definitions of a smart cities (Source: own elaboration on the based Hall 2000; Florida 2002; Komninos 2006; Giffinger et al. 2007; Hollands 2008; Caragliu et al. 2011; Nam, Pardo 2011; Lombardi et al. 2012)

\begin{tabular}{|c|c|c|}
\hline Authors & Years & Definitions \\
\hline Hall & 2000 & $\begin{array}{l}\text { A city that monitors and integrates conditions of all its critical infrastructure, including roads, } \\
\text { bridges, tunnels, rails, subways, airports, seaports, communications, water, power, even major } \\
\text { buildings, can better optimize its resources, plan its preventive maintenance activities, and } \\
\text { monitor security aspects while maximizing services to its citizens }\end{array}$ \\
\hline Florida & 2002 & $\begin{array}{l}\text { Applied by city officials, urban planners, businesses and anyone interested in city development } \\
\text { today with the goal of redefining the city as a creative center }\end{array}$ \\
\hline Komninos & 2006 & $\begin{array}{l}\text { A cities are territories with high capacity for learning and innovation, which is built in the crea- } \\
\text { tivity of their population, their institutions of knowledge creation and their digital infrastructure } \\
\text { for communication and knowledge management }\end{array}$ \\
\hline $\begin{array}{l}\text { Giffinger } \\
\text { et al. }\end{array}$ & 2007 & $\begin{array}{l}\text { A digital platform on which a complex ecosystem of multiple agents (including administration, } \\
\text { companies and citizens) is development, equipped with sensors and capable of offering, } \\
\text { through the processing of all the information acquired by the sensor network, the best services } \\
\text { possible at every moment }\end{array}$ \\
\hline Hollands & 2008 & $\begin{array}{l}\text { It is the implementation and deployment of information and communication technology infra- } \\
\text { structures to support social and urban growth through improving the economy, citizens' in- } \\
\text { volvement efficiency }\end{array}$ \\
\hline $\begin{array}{l}\text { Caragliu } \\
\text { et al. }\end{array}$ & 2011 & $\begin{array}{l}\text { Safe, secure, environmental and efficient urban centre of the future with advanced infrastruc- } \\
\text { tures such as sensors, electronic devices and networks to stimulate sustainable economic } \\
\text { growth and a high quality of life }\end{array}$ \\
\hline $\begin{array}{l}\text { Nam, } \\
\text { Pardo }\end{array}$ & 2011 & $\begin{array}{l}\text { A smart city infuses information into its physical infrastructure to improve conveniences, fa- } \\
\text { cilitate mobility, add efficiencies, conserve energy, improve the quality of air and water, identi- } \\
\text { fy problems and fix them quickly, recover rapidly from disasters, collect data to make better } \\
\text { decisions, deploy resources effectively, and share data to enable collaboration across entities } \\
\text { and domains }\end{array}$ \\
\hline $\begin{array}{l}\text { Lombardi } \\
\text { et al. }\end{array}$ & 2012 & $\begin{array}{l}\text { The application of information and communications technology with effects on human capi- } \\
\text { tal/education, social and relational capital, and environmental issues is often indicted by the } \\
\text { notion of smart city }\end{array}$ \\
\hline
\end{tabular}


Researchers emphasize the importance of the integration of a city's various systems such as transportation, energy, education, health care, technical infrastructure, public safety in creating a smart city (Papa et al. 2013). Giffinger and Gudrum identified six main components of a smart city. These elements include a smart economy, smart mobility, a smart environment, smart people, smart living, and smart governance (Giffinger, Gudrun 2010). In this area scientists rely on traditional theories of urban growth and development: regional competitiveness, transport and ICT economics, natural resources, quality of life. However, many researchers argue that the last component does not represent a separate dimension of a smart city because all the operations performed in other areas should have the objective of raising the quality of life. Lombardi et al. have linked these components with different aspects of urban life. For instance, smart economy has been connected with the presence of ICT enterprises (Lombardi et al. 2012). Nam and Pardo mark out technology, people (creativity, diversity, education) and institutions (governance, policy) (Nam, Pardo 2011). A city becomes truly smart when investment in human and social capital, together with ICT infrastructure, creates sustainable development. The Table 2 presents components of a smart city.

Table 2. Components of a smart city (Source: own elaboration on the based Eger 2009; Giffinger, Gudrun 2010; Nam, Pardo 2011; Kourtit, Nijkamp 2012; ISO 37120:2014)

\begin{tabular}{l|c|l}
\hline \multicolumn{1}{c|}{ Authors } & Years & \multicolumn{1}{c}{ Components } \\
\hline Eger & 2009 & $\begin{array}{l}\text { technology, economic develop- } \\
\text { ment, job growth, quality of life }\end{array}$ \\
\hline $\begin{array}{l}\text { Giffinger, } \\
\text { Gudrum }\end{array}$ & 2010 & $\begin{array}{l}\text { economy, mobility, environment, } \\
\text { people, living, governance }\end{array}$ \\
\hline $\begin{array}{l}\text { Nam, } \\
\text { Pardo }\end{array}$ & 2011 & $\begin{array}{l}\text { economic socio-political issues } \\
\text { of the city, economic-technical- } \\
\text { social issue of the environment, } \\
\text { interconnection, instrumentation, } \\
\text { integration, applications, innova- } \\
\text { tions }\end{array}$ \\
\hline $\begin{array}{l}\text { Kourtit, } \\
\text { Nijkamp }\end{array}$ & 2012 & $\begin{array}{l}\text { human capital, infrastructural } \\
\text { capital, social capital, entrepre- } \\
\text { neurial capital }\end{array}$ \\
\hline ISO 37120 & 2014 & $\begin{array}{l}\text { city services: education, finance, } \\
\text { fire and emergency response, } \\
\text { governance, health, recreation, } \\
\text { safety, solid, transportation, ur- } \\
\text { ban planning, wastewater, water } \\
\text { quality of life: economy, envi- } \\
\text { ronment, shelter, telecommuni- } \\
\text { cation and innovation }\end{array}$ \\
\hline
\end{tabular}

Various methods and measurement indices were created according to the several meanings of the concept of a smart city. Rating systems using synthetic quantitative indicators are receiving increasing attention among city managers and policy makers and are to utilized to decide where to focus resources, as well as how to enhance the city's performance. Nowadays every city needs indices to measure its performance but existing indicators are usually not standardized, inconsistent and incomparable. The ISO 37120 standard is a set of standardized indicators which provide a uniform approach to what is measured and how that measurement is performed (Steele 2014). In general, ISO 37120 defines indicators divided into 17 themes (Tillie 2014; Lynch 2015). These indicators can be used to track and monitor progress of a city's sustainable development. Planning for future needs must take into consideration current effectiveness of resource use (McCarney 2015). The indicators have been developed in order to help cities learn from one another by allowing comparisons across a wide range of performance measures and sharing best practices.

\section{Research methodology}

Classification of Polish cities from point of view of their smartness was examined using Z. Hellwig's method, based on the synthetic indicators. Hellwig's taxonomic method is based on the construction of an abstract object $\mathrm{P}_{\mathrm{o}}$, called the pattern of development (Strahl 1978; Nowak 1990). In this study, the meter was used to organize Polish cities according to the attained level of smartness. Included diagnostic variablles are first subjected to standardization. In the next stage characteristics of the variables taken into account were specified, among with stimulants and destimulants of development were distinguished. The pattern of development has been defined as an object characterized by the highest values for stimulants and smallest for destimulants. The distance between the cities and the object $\mathrm{P}_{\mathrm{o}}$ is calculated as Euclidean distance.

The test procedure consisted of the following steps (Strahl 1978; Nowak 1990; Grabiński 1992; Młodak 2006, 2012; Panek 2009; Olszewska 2014):

- normalizing of the set of variables using the following formula:

$$
z_{i j}=\frac{x_{i j}-\overline{x_{j}}}{s_{j}},
$$


where: $z_{i j}$ - the standardized value of the $j$-th variable on object $i$;

$x_{i j}$ - the value of the $j$-th variable on object $i$;

$\overline{x_{j}}$ - the mean value of the $j$-th variable;

$s_{j}-$ the standard deviation of the $j$-th variable;

- calculating Euclidean distance $c_{i o}$ appllying the following formula:

$$
c_{i o}=\left\{\begin{array}{l}
\sqrt{\sum_{i=1}^{n}\left(x_{i j}-x_{\max }\right)^{2}} \text { for stimulants } \\
\sqrt{\sum_{i=1}^{n}\left(x_{i j}-x_{\min }\right)^{2}} \text { for destimulants }
\end{array},\right.
$$

where: $x_{\max }-$ the maximum value of the $j$-th variable;

$x_{\min }$ - the minimum value of the $j$-th variable;

- count the critical distance between objects and the "ideal object" $c_{o}$ using the following formula:

$$
c_{o}=\frac{1}{n} \sum_{i=1}^{n} c_{i o} 2 \sqrt{\frac{1}{n} \sum_{i=1}^{n}\left(c_{i o}-\overline{c_{o}}\right)^{2}},
$$

- count the synthetic measure of development proposed by Hellwig $d_{i}$ by the following formula:

$$
d_{i}=1-\frac{c_{i o}}{c_{o}},
$$

where: $d_{i}-$ the taxonomic measure of development proposed by Hellwig;

$c_{o}$ - the critical distance between objects and the "ideal object";

- grouping on the based value of the synthetic measure all the cities into four groups:

\begin{tabular}{ll}
\hline I class & if the synthetic measure is \\
& $d_{i}>\overline{d_{i}}+S_{d i}$ \\
II class & if the synthetic measure is \\
& $\overline{d_{i}} \leq d_{i}<\overline{d_{i}}+S_{d i}$ \\
III class & if the synthetic measure is \\
& $\overline{d_{i}}-S_{d i} \leq d_{i}<\overline{d_{i}}$ \\
IV class & if the synthetic measure is \\
& $d_{i} \leq \overline{d_{i}}-S_{d i}$
\end{tabular}

where: $\overline{d_{i}}$ the average of the taxonomic measure $d_{i}$;

$S_{d i}$ - the standard deviation of the taxonomic measure $d_{i}$.

\section{Results and discussion}

To evaluate the level of smartness of Polish cities Hellwig's method was applied. Analysis data was supplied by the Local Data Bank of the Central Statistical Office for the year 2014 covering 304 Polish urban gminas. Seventy of these cities have full coverage planning. Polish cities are covered in 55.7 percent by local plans (Śleszyński et al. 2015). Based on the review of literature mentioned above, the author adopted the following indicators as thirteen diagnostic variables. For each city thirteen indicators which represent different components of the ISO 37120 Standard have been calculated. Nine variables represent city services and four variables apply to the quality of life. Two variables are destimulants $\left(\mathrm{X}_{3}, \mathrm{X}_{6}\right)$ and remaining eleven variables are stimulants. All statistical analyses in this article were performed using the Microsoft Office Excel 2010 software. The Table 3 outlines indicators of a smart city and components of ISO 37120 Standard.

Classification by synthetic measure calculated by Hellwig, based on thirteen selected features, identified as the most smartness cities in 2014 Krynica Morska and a synthetic index amounts 0.28 . This city has the highest total revenue reaching 23,897.38 PLN per capita. Calculated synthetic smartness indicator allowed the isolation of groups of cities characterized by a similar level of smartness. In this way, four classes of cities were identified:

- Group I: the cities with the highest smartness,

- Group II: the cities with the middle rate of smartness,

- Group III: the cities with a low rate of smartness,

- Group IV: the cities with the lowest rate of smartness.

The group with the highest smartness includes 42 cities and a synthetic index amounts $d_{i}>0.11$. This class includes most Polish metropolitan cities (Wrocław, Katowice, Poznań, Kraków), tourist cities (Sopot, Łeba, Jastarnia, Władysławowo), suburban cities (Podkowa Leśna, Zielonka, Pruszcz Gdański) and post-mining cities (Chorzów, Gliwice, Siemianowice Śląskie). The capital of Poland ranks a distant fifth position within this group. This class is characterized by the smallest area covered by local plans. Karpacz has the largest number of entities entered in the REGON register at 7692 per 10 thousand of population. Józefów has the largest share of newly-registered creative sector entities within the total number of newlyregistered entities reaching 13.4 percent. 
Table 3. Indicators of a smart city vs. components of ISO 37120 Standard (Source: own elaboration on the based the Local Data Bank of the Central Statistical Office (2014), the World Council on City Data (2014) and Standard ISO 37120: 2014)

\begin{tabular}{|c|c|c|}
\hline Variables & Components of ISO 37120 & Indicators \\
\hline $\mathrm{X}_{1}$ & urban planning & share of the area covered by local plans in the total city area in percent \\
\hline $\mathrm{X}_{2}$ & finance & total revenue per capita \\
\hline $\mathrm{X}_{3}$ & solid waste & mixed municipal waste collected during the year per capita \\
\hline $\mathrm{X}_{4}$ & transportation & urban transportation routes bus per 100 hectares of area \\
\hline $\mathrm{X}_{5}$ & education & number of pupils per 1 computer with broadband Internet access \\
\hline $\mathrm{X}_{6}$ & water & $\begin{array}{l}\text { consumption of water for needs of the national economy and population } \\
\text { during the year per capita }\end{array}$ \\
\hline $\mathrm{X}_{7}$ & recreation & share of green areas in the total area in percent \\
\hline $\mathrm{X}_{8}$ & health & health out-patient departments per 10 thousand population \\
\hline $\mathrm{X}_{9}$ & wastewater & share of population connected to municipal wastewater treatment plants \\
\hline $\mathrm{X}_{10}$ & governance & share of woman of total elected to city-level office \\
\hline- & energy & none \\
\hline- & fire \& emergency response & none \\
\hline- & safety & none \\
\hline- & shelter & none \\
\hline $\mathrm{X}_{11}$ & economy & entities entered in the REGON register per 10 thousand population \\
\hline $\mathrm{X}_{12}$ & environment & share of legal protected in total area in percent \\
\hline $\mathrm{X}_{13}$ & $\begin{array}{l}\text { telecommunication \& inno- } \\
\text { vation }\end{array}$ & $\begin{array}{l}\text { share of new-registered creative sector entities in the total number of new- } \\
\text { registered entities }\end{array}$ \\
\hline
\end{tabular}

The group with the middle rate of smartness consists of 91 cities and a synthetic index amounts $0.07<d_{i} \leq 0.11$. The low ranking of the city of Torun, the largest regional city, should be noted (it is 64 position). This class is characterized by the highest share of area covered by local plans and the highest computerization rate in primary and secondary schools.

The third group with a low rate of smartness includes 143 cities and a synthetic index amounts $0.036<d_{i} \leq 0.072$.
The fourth group consists of 28 cities and a synthetic index amounts $d_{i} \leq 0.036$. The last position on the list of cities belongs to Konin. This city has the largest consumption of water for needs of the national economy and population reaching $17,904.1 \mathrm{~m}^{3}$ per capita because of the location of its power plant Pątnów-Adamów-Konin. The Table 4 presents the ranking of Polish cities. 
Table 4. Cities ranking base on synthetic variable (Source: own calculations on the based the Local Data Bank of the Central Statistical Office (2014))

\begin{tabular}{|c|c|c|c|}
\hline Ranking & $\begin{array}{c}\text { Level of } \\
\text { smartness }\end{array}$ & Criterion & Cities \\
\hline I & High & $\mathrm{di}>0.108$ & $\begin{array}{l}\text { Krynica Morska, Podkowa Leśna, Sopot, Karpacz, Warszawa, Wrocław, } \\
\text { Katowice, Poznań, Łeba, Kraków, Jastarnia, Chorzów, Zamość, Koło- } \\
\text { brzeg, Władysławowo, Gliwice, Białystok, Lublin, Łódź, Ustroń, Opole, } \\
\text { Świeradów Zdr., Gdańsk, Wisła, Zielonka, Kielce, Olsztyn, Siemiano- } \\
\text { wice Śl., Ciechocinek, Siedlce, Józefów, Pruszcz Gd., Świnoujście, Kro- } \\
\text { sno, Bielsko Biała, Tarnowskie Góry, Człuchów, Gdynia, Zielona Góra, } \\
\text { Szczawno Zdr., Leszno, Stupsk, Ustka }\end{array}$ \\
\hline II & Middle & $0.072<\mathrm{di} \leq 0.108$ & $\begin{array}{l}\text { Cieszyn, Rzeszów, Zakopane, Maków Maz., Puszczykowo, Lidzbark } \\
\text { Warm., Polanica Zdr., Kalisz, Dabrowa Górn., Bydgoszcz, Szczecin, } \\
\text { Tychy, Górowo Iławieckie, Milanówek, Koszalin, Ostróda, Płock, Go- } \\
\text { rzów Wielk., Jelenia Góra, Częstochowa, Toruń, Nowy Sacz, Piastów, } \\
\text { Kościan, Żyrardów, Szklarska Poręba, Przemyśl, Tomaszów Lubelski, } \\
\text { Grudziqdz, Mikołów, Legionowo, Świdnica, Żywiec, Sosnowiec, Boch- } \\
\text { nia, Ząbki, Legnica, Tarnów, Wagrowiec, Mszana Dln., Chełm, Będzin, } \\
\text { Limanowa, Piotrków Tryb., Szczyrk, Giżycko, Otwock, Radom, Ra- } \\
\text { dzionków, Pruszków, Przasnysz, Bytom, Bolesławiec, Koło, Łomża, } \\
\text { Zabrze, Luboń, Sulejówek, Rybnik, Kętrzyn, Rawa Maz., Skierniewice, } \\
\text { Włocławek, Czeladź, Puck, Sandomierz, Malbork, Płońsk, Złotów, } \\
\text { Brzeziny, Biała Podl., Tarnobrzeg, Nowe Miasto Lubawskie, Słupca, } \\
\text { Lębork, Wysokie Maz., Sucha Beskidzka, Marki, Brzeg, Kłodzko, Ru- } \\
\text { mia, Gubin, Głogów, Czarnków, Lańcut, Nowy Targ, Szczecinek, Su- } \\
\text { wałki, Chodzież }\end{array}$ \\
\hline III & Low & $0.036<\mathrm{di} \leq 0.072$ & $\begin{array}{l}\text { Dusznik Zdr., Kraśnik, Pabianice, Hel, Łowicz, Oświęcim, Piekary Śl., } \\
\text { Mysłowice, Ostrów Wielk., Garwolin, Darłowo, Zawiercie, Zgierz, El- } \\
\text { blag, Mragowo, Tczew, Ruda Śl., Ciechanów, Stoczek Łukowski, } \\
\text { Świdnik, Kobyłka, Zduńska Wola, Puławy, Golice, Biłgoraj, Szczytno, } \\
\text { Bełchatów, Świdwin, Lubliniec, Zgorzelec, Ełk, Wejherowo, Inowro- } \\
\text { cław, Żary, Kutno, Radlin, Dzierżoniów, Bartoszyce, Chojnice, Piła, } \\
\text { Łęknica, Wałbrzych, Jaworzno, Złotoryja, Kwidzyn, Chojnów, Łęczyca, } \\
\text { Chełmno, Wojkowice, Przeworsk, Knurów, Sokołów Podl., Jordanów, } \\
\text { Reda, Mińsk Maz., Iława, Żagań, Żory, Kędzierzyn-Koźle, Węgrów, } \\
\text { Lubawa, Bukowno, Imielin, Gniezno, Ostrołęka, Brodnica, Lubań Mie- } \\
\text { lec, Wałcz, Lubin, Kościerzyna, Radomsko, Sochaczew, Kudowa-Zdrój, } \\
\text { Brańsk, Racibórz, Ostrów Maz., Świętochłowice, Białogard, Konstan- } \\
\text { tynów Łódz., Siemiatycze, Nowy Dwór Maz., Międzyrzec Podl., Star- } \\
\text { gard Szczec., Jarosław, Bielsk Podl., Działdowo, Lubartów, Oleśnica, } \\
\text { Golub-Dobrzyń, Starachowice, Lipno, Hrubieszów, Sanok, Łuków, } \\
\text { Tomaszów Maz., Rydułtowy, Krasnystaw, Oława, Ostowiec Święt., } \\
\text { Kostrzyn n. Odra, Sieradz, Mława, Wąbrzeźno, Sławków, Hajnówka, } \\
\text { Leżajsk, Świebodzice, Skarżysko-Kamienna, Nowa Sól, Jasło, Augu- } \\
\text { stów, Radzyń Podl., Bielawa, Jedlina Zdr., Łaskarzew, Bieruń, Dębica, } \\
\text { Wodzisław Śl., Myszków, Jastrzębie Zdr., Laziska Grn., Włodawa, Sej- } \\
\text { ny, Rypin, Lubaczów, Radziejów, Dynów, Stalowa Wola, Raciąż, Lę- } \\
\text { dziny, Ozorków, Turek, Aleksandrów Kuj., Kowary, Niszawa, Staro- } \\
\text { gard Gd., Sierpc, Grajewo, Braniewo, Pyskowice, Jawor }\end{array}$ \\
\hline IV & Very low & $\mathrm{di} \leq 0.036$ & $\begin{array}{l}\text { Zambrów, Sławno, Głowno, Piechowice, Skórcz, Kamienna Góra, Tere- } \\
\text { spol, Chełmża, Nowa Ruda, Dęblin, Grybów, Kalety, Obrzycko, Woj- } \\
\text { cieszów, Kolno, Miasteczko Śl., Gostynin, Pszów, Rejowiec Fabr., Bo- } \\
\text { guszów-Gorce, Orzesze, Poręba, Radymno, Sulmierzyce, Piława Grn., } \\
\text { Zawidów, Gozdnica, Konin }\end{array}$ \\
\hline
\end{tabular}

Wrocław voivodeship cities

Świnoujście cities with poviat status 


\section{Conclusions}

The literature review in the context of urban spatial management shows that the concept of a smart city is a popular subject of scientific research. There are a lot of definitions and classification of components of a smart city. The most practical methods to measure a city's performance is through the use of the ISO 37120 Standard. One of the dimension of a smart city is urban planning. Smart cities should implement good quality local spatial development plans.

Through the application of the taxonomic method using Hellwig's composite measure of development Polish cities were compared using thirteen indicators. The author divided the cities of Poland into four independent classes. The results obtained were used to rank the analyzed cities in terms of their levels of smartness. The most smartness cities proved Polish metropolises (Wrocław, Katowice, Poznań, Kraków), tourist cities (Sopot, Łeba, Jastarnia, Władysławowo), suburban cities (Podkowa Leśna, Zielonka, Pruszcz Gdański) and post-mining cities (Chorzów, Gliwice, Siemianowice Ślaskie). The analysis presented a need to improve city services and the quality of life in cities falling into the fourth class.

Possible areas for future research may include issues such as business models for smart city organizations. Finally, the author hopes that this study will encourage policy makers and city managers to implement the ISO 37120 Standard in their urban systems which will facilitate the monitoring of city services.

\section{References}

Allwinkle, S.; Cruickshank, P. 2011. Creating smarter cities: an overview, Journal of Urban Technology 18(2): 1-16. http://dx.doi.org/10.1080/10630732.2011.601103

Bakici, T.; Almirall, E.; Wareham, J. 2013. A smart city initiative: the case of Barcelona, Journal of the Knowledge Economy 4: 135-148. http://dx.doi.org/10.1007/s13132-012-0084-9

Batagan, L. 2011. Smart cities and sustainability models, Revista de Informatica Economica 15(3): 1305-1453.

Caragliu, A.; del Bo, C.; Nijkamp, P. 2011. Smart cities in Europe, Journal of Urban Technology 18(2): 65-82. http://dx.doi.org/10.1080/10630732.2011.601117

Chourabi, H.; Nam, T.; Walker, S.; Gil-Garcia, J. R.; Mellouli, S.; Nahon, K.; Pardo, T. A.; Scholl, H. J. 2012. Understanding smart cities: an integrative framewrok, in $45^{\text {th }}$ Hawai International Conference on System Sciences, 4-7 January, Maui, HI. Piscataway, NJ: IEEE, 2289-2297.

http://dx.doi.org/10.1109/hicss.2012.615
Cocchia, A. 2014. Smart and digital city: a systematic literature review, in R. P. Dameri, C. Sabroux (Eds.). Smart city: how to create public and economic value with high technology in urban space. Switzerland: Springer International Publishing, $13-43$. http://dx.doi.org/10.1007/978-3-319-06160-3_2

Dameri, R. P. 2013. Searching for smart city definition: a comprehensive proposal, International Journal of Computers \& Technology 11(2): 2544-2551.

Dameri, R. P.; Cocchia, A. 2013. Smart city and digital city: twenty years of terminology evolution, in ItAIS2013, X Conference of the Italian Chapter of AIS, 14 December 2013, Milano, Italy.

Eger, J. M. 2009. Smart growth, smart cities, and crisis at the pump a worldwide phenomenon, I-Ways 32(1): 47-53.

European Union 2014. Mapping of Smart Cities in the $E U$ [online]. Brussels [cited 20 January 2016]. Available from Internet:

http://www.europarl.europa.eu/RegData/etudes/etu des/join/2014/507480/IPOL-ITRE_ET\%282014\% 29507480_EN.pdf

Florida, R. 2002. The rise of the creative class and how it's transforming work, leisure, community, and everyday life. New York: Basic Books.

Giffinger, R.; Fertner, C.; Kramar, H.; Kalasek, R.; Pichler-Milanoić, N.; Meijers, E. 2007. Smart cities. Ranking of European medium-size cities [online]. Centrel of Regional Science (SRF). University of Technology, Vienna [cited 20 January 2016]. Available from Internet: http:///www.smartcities.eu/download/smart_cities_final_report.pdf

Giffinger, R.; Gudrun, H. 2010. Smart cities rankimg: an effective instrument for the positioning of cities?, ACE Architecture 4(12): 7-25.

Grabiński, T. 1992. Metody taksonometrii. Akdemia Ekonomiczna, Kraków.

Hall, P. 2000. Creative cities and economic development, Urban Studies 37(4): 633-649. http://dx.doi.org/10.1080/00420980050003946

Hernández-Muňoz, J. M.; Vercher, J. B.; Muňoz, L.; Galache, J. A.; Presser, M.; Gómez, L A. H.; Pettersson, J. 2011. Smart cities at the forefront of the future internet. Berlin: Springer. http://dx.doi.org/10.1007/978-3-642-20898-0_32

Hollands, R. 2008. Will the real smart city please stand up?, City 12(3): 303-320. http://dx.doi.org/10.1080/13604810802479126

ISO 37120:2014. Sustainable Development of Communities: Indicators for City Services and Quality of Live [online], [cited 31 January 2016]. Available from Internet:

http://publicaa.ansi.org/sites/apdl/ANSI\%20Netwo rk\%20on\%20Smart\%20and\%20Sustainable \%20Ci ties/ISO+37120-2014_preview_final_v2.pdf 
Komninos, N. 2006. The architecture of intelligent cities: integrating human, collective, and artifcial intelligent to enhance knowledge and innovation, in $2^{\text {nd }}$ International Conference Intelligent Environment, 5-6 July 2006, Athens, 13-20.

http://dx.doi.org/10.1049/cp:20060620

Kourtit, K.; Nijkamp, P. 2012. Smart cities in the innovation age, Innovation: The European Journal of Social Science Research 25: 93-95. http://dx.doi.org/10.1080/13511610.2012.660331

Leydesdorff, L.; Deakin, M. 2011. The Triple-Helix Model of smart cities: a neo-evolutionary perspective, Journal of Urban Technology 18: 53-63. http://dx.doi.org/10.1080/10630732.2011.601111

Lierow, M. 2014. B2City: the next wave of urban logistics [online], [cited 30 January 2016]. Available from Internet:

www.supplychain247.com/paper/b2city_the_next_ wave_of_urban_logistics

Local Data Bank of the Central Statistical Office [online]. 2014 [cited 29 January 2016]. Available from Internet: https://bdl.stat.gov.pl/BDL

Lynch, M. 2015. Standardized indicators for resilient cities: ISO 37120 \& The World Council on City Data [online], [cited 30 January 2016]. Available from Internet:

http://resilientcities2015.iclei.org/fileadmin/RC201 5/files/pptx/Opening_Plenary_Lynch.pdf

Lombardi, P. 2011. New challenges in the evaluation of smart cities, Network Industries Quarterly 13(3): 8-10.

Lombardi, P.; Giordano, S.; Farouh, H.; Yousef, W. 2012. Modelling the smart city performance, Innovation: The European Journal of Social Science Research 25(2): 137-149. http://dx.doi.org/10.1080/13511610.2012.660325

McCarney, P. 2015. The evolution of global city indicators and ISO37120: the first international standard on city indicators, Statistical Journal of the IAOS 31: 103-110.

Młodak, A. 2006. Analiza taksonomiczna $w$ statystyce regionalnej [Taxonomic analysis in regional statistics]. Difin, Warszawa (in Polish).

Młodak, A. 2012. Statystyka metropolii polskich -problemy i pespektywy [Statistics of Polish metropolis - problems and prospects], Studia Regionalne i Lokalne 2: 20-38 (in Polish).

Nam, T.; Pardo, T. A. 2011. Conceptualizing Smart City with Dimensions of Technology, people and institutions, in $12^{\text {th }}$ Annual Digital Government Research Conference, College Park, 282-291. http://dx.doi.org/10.1145/2037556.2037602

Nowak, E. 1990. Metody taksonomiczne w klasyfikacji obiektów spoleczno-gospodarczych [Taxonomic methods in the classification of socio-economic objects]. PWN, Warszawa (in Polish).

Olszewska, A. 2014. Wykorzystanie wybranych metod taksonomicznych do oceny potencjału innowacyj- nego województw [The use of selected taxonomic methods for evaluating the innovative capability of regions], in K. Jajuga, M. Walesiak (Eds.). Taksonomia. Klasyfikacja $i$ analiza danych - teoria $i$ zastosowania 328: 167-176 (in Polish).

Panek, T. 2009. Statystyczne metody wielowymiarowej analizy porównawczej [Statistical methods of multidimensional comparative analysis]. Warszawa: Szkoła Główna Handlowa (in Polish).

Papa, R.; Garguilo, C.; Galderisi, A. 2013. Towards and urban planners' perspective on smart city, TeMA Journal of Land Use, Mobility and Environment 6(1): 5-17.

Paskaleva, K. A. 2009. Enabling the smart city: the progress of city e-governance in Europe, International Journal of Innovation and Regional Development 1(4): 405-422. http://dx.doi.org/10.1504/IJIRD.2009.022730

Ricciardi, F.; Za, S. 2014. Smart city research as in interdisciplinary crossroads: a challenge for management and organization studies, in L. Mola, F. Pennarola, S. Za (Eds.). From information to smart society: environment, politics and economics. Lecture notes in information system and organisation, Switzerland: Springer International Publishing, 163-171.

Richter, C.; Kraus, S.; Syrjä, P. 2015. The smart city as an opportunity for entrepreneurship, International Journal Entrepreneurial Venturing 7: 211-226. http://dx.doi.org/10.1504/IJEV.2015.071481

Sainz Pena, R. M. 2011. Smart cities: a first step towards the internet of things. Fundacion Telefonica, Ariel, Barcelona.

Schaffers, H.; Komninos, N.; Pallot, M.; Trousse, B.; Nilsson, M.; Olveira, A. 2011. Smart cities and the future internet: towards cooperation frameworks for open innovation, in J. Domingue, et al. (Eds.). The Future Internet: Future Internet Assembly 2011, Achievements and Technological Promises. Heidelberg: Springer, 431-446. http://dx.doi.org/10.1007/978-3-642-20898-0_31

Shapiro, J. M. 2006. Smart cities: quality of life, productivity, and the growth effects of human capital, The Review of Economics and Statistics 88: 324-335.

http://dx.doi.org/10.1162/rest.88.2.324

Steele, R. 2014. ISO 37120 standard on city indicators - how they help city leaders set tangible targets, including service quality and quality of life [online], Centre for Liveable Cites, Singapore [cited 29 January 2016]. Available from Internet: http://www.clc.gov.sg/documents/Lectures/2014/C LC-2014-Rob-steele-Terry-Hill.pdf

Strahl, D. 1978. Propozycja konstrukcji miary syntetycznej [Proposed structure of synthetic measure], Przeglad Statystyczny 2 (in Polish).

Śleszyński, P.; Komornicki, T.; Deręgowska, A.; Zielińska, B. 2015. Analiza stanu $i$ uwarunkowań prac 
planistycznych $w$ gminach $w 2013$ roku [Analysis of state and conditions of planning work in municipalities in 2013], [online], Instytut Geografii i Przestrzennego Zagospodarowania PAN, Warszawa [cited 30 January 2016]. Available from Internet: https://www.mr.gov.pl/media/5139/analiza 2013.pdf

Tachizawa, E. M.; Alvarez-Gil, M. J.; MontesSancho, M. J. 2015. How "smart cities" change supply chain management, Supply Chain Management: An International Journal 20(3): 237248.

Tillie, N. 2014. Innovation in assessing and governing low carbon and smart cities, World Consul on City Data [online], [cited 30 January 2016]. Available from Internet:

http://iet.jrc.ec.europa.eu/energyefficiency/sites/en ergyefficiency/files/files/documents/events.pdf
Tranos, E.; Gertner, D. 2012. Smart Networked Cities?, Innovation: The European Journal of Social Science Research 25: 175-190.

http://dx.doi.org/10.1080/13511610.2012.660327

United Nation. 2015. World urbanization prospect: the 2014 revision [online]. Department of Economic and Social Affairs, Population Division, New York [cited 29 January 2016]. Available from Internet: http://esa.un.org/unpd/wup/FinalReport/WUP2014 -Report.pdf

World Council on City Data [online]. 2014 [cited 30 January 2016]. Available from Internet: http://www.dataforcities.org 